\title{
1st International Symposium on Groundwater Ecology. Introduction: Sense and Course of the Meeting
}

\author{
by
}

\author{
Siegfried HUSMANN*
}

During the last decenniums ecological investigations of subterranean waters received an increasing interest from many sides. The cause is that the young field of limnological activities produced new problems for all scientists working on biotopes and biocenoses of groundwater organisms. For example, hydrogeology, speleology, stygochemistry and groundwater ecology have many common problems because groundwater fills a system of interstices and caverns of different volumes in various petrological materials. Moreover many common problems of groundwater ecology and groundwater hygienics arose from the fact that groundwater in layers of sand and gravel represents the characteristic biotope for groundwater organisms as well as being the most important reservoir of drinking water.

Until now the knowledge of groundwater organisms as well as information about the effectivity of ecological factors in groundwaters were still relatively limited. Nearly all disciplines of scientific research on subterranean waters, which in the future will form "groundwater ecology", are still in the initial stages of development. The term "groundwater ecology" as used here is to be considered as describing a program rather than an established science. A more comprehensive knowledge of the groundwater ecosystem may only be achieved by integrating the results of zoosystematics, biocoenology, physiology, hydrogeology, chemistry, hygienics, zoogeography and other aspects of the subject. All students working in these fields may be called "groundwater ecologists" because their studies form the elements of "groundwater ecology". Both terms, "groundwater ecology" as well as "groundwater ecologists" shall here be used in such a broad sense.

In order to perceive distinct contours of "groundwater ecology" most stygolimnologists are obviously interested about results obtained by other 
groundwater specialists. They are also in favour of opportunities for personal exchanges of ideas. This became obvious when first suggestions for a "meeting of groundwater ecologists" met with world-wide warm reponse.

The idea to arrange a symposium on groundwater ecology was stimulated when the "IIIrd International Colloquium on Gammarus and Niphargus" was organized here at Schlitz by Dr. M. P. D. Meijering.

Based on the well-known phenomenon that the very numerous species of the genus Niphargus are characteristic elements in groundwater - biocoenoses, papers about Niphargus may be regarded as contributions to both fields of investigation: Gammarus-Niphargus-research and groundwater ecology. This reflection encouraged me to suggest a combined meeting of scientists working in both these fields of limnology.

Dr. Meijering agreed with this plan and we then began to organize jointly the combined meetings

"IIIrd International Colloquium on Gammarus and Niphargus"

"Ist International Symposium on Groundwater Ecology"

Both meetings were sponsored by the river-station (Limnologische Flussstation) at Schlitz, a "town of castles" in Hesse (West Germany, with 1200 years of history) and received financial support from the "Deutsche Forschungsgemeinschaft" and much help from the town council of Schlitz, especially from Burgomaster Siegfried Klee.

In 1949, the river station was founded with the aid of Graf Otto Hartmann von Goertz genannt von Schlitz, and limnological investigations of the Fulda drainage system were started. In 1951 this "Fulda-Station" was incorporated into the "Hydrobiologische Anstalt der Max-Planck-Gesellschaft (formerly "Kaiser-Wilhelm-Gesellschaft") (Dir. A. Thienemann), which is now called "Max-Planck-Institut für Limnologie". The Limnologische Flusstation belongs to the Department of General Limnology (Dir. J. Overbeck) of the M.P.I. für Limnologie. Leader of the station is J. Illies (limnozoology); the other members of staff are J. Brehm (limnochemistry), S. Husmann (groundwater ecology) and P. Zwick (limnozoology). Now the station is mainly involved in research on the productivity of running waters.

The combined meetings were held in the knights' hall of the Vorderburg, a castle built in 1000 A.D. 28 papers on "groundwater ecology" were read, including 11 presentations concerning the stygobiont genera Niphargus, Crangonyx and other stygobiont amphipods. These latter papers (list of authors and titles see page 6) will be published together with those on Gammarus as a supplement of "Crustaceana".

Papers relating to problems of groundwater ecology dealt with various aspects of it: systematics, bionomics, histophysiology, karyology, dynamics, rhythmic activity, zoogeography, hydrogeology, krenology, sandfiltration and hygiene.

This wide field of problems initiated many-sided discussions which like the papers themselves provided useful information for groundwater ecologists as well as for Niphargus researchers.

In addition, the participants of our combined meetings found favourable 
possibilities for personal and scientific contacts during special discussion groups as well as during excursions in the environs of Schlitz, where biotopes of groundwater organisms and methods for groundwater investigations were demonstrated. For example, we visited a biotope of Niphargus schellenbergi on a slope of the "Wasserkuppe", the highest elevation of the "Rhön-mountains". Here a population of our amphipod lives in a secondary source flowing out of the gravel bed of the Fulda, which usually dries up in this zone during long periods without precipitation.

At the foot of the "Wasserkuppe", near the town Gersfeld, an apparatus for pumping groundwater and organisms from different depths of the sand and gravel bed of the Fulda was demonstrated. Another installation used for similar investigations was visited in the Fulda valley near the town of Fulda: a pipe station (Peilrohr-Station) which is situated about $150 \mathrm{~m}$ from the river (detailed description in this Journal, Vol. 6, 271-302).

In high spirits the day's excursion was finished by a "Schlitz beer party" which took place in an old vault of the Schlitz beer brewery, where personal communications of the day continued further. The participants of our meetings did not only find personal contacts among themselves, but a reception of the town council was an event which also provided possibilities for communication between the people of Schlitz and their guests.

Encouraged by personal contacts, many ideas and stimulations for their work, the groundwater specialists decided to maintain personal connections by distributing an "International Groundwater Newsletter". The series shall be prepared at Schlitz initially but later will be continued by groundwater specialists in other countries. Besides various groundwater news the Newletter will contain information about the organisation of future International Symposia on Groundwater Ecology. These meetings shall be arranged every three years, as unanimously decided by the participants of our symposium.

In view of the many common interests of groundwater ecologists and Niphargus specialists the majority of participants of both colloquia wished to again combine their next international meetings. Colleagues A. L. Buikema and J. Holsinger offered the arrangement of a combined meeting in Blacksburg, Virginia, U.S.A.: 4th International Colloquium on Gammàrus and Niphargus" and "IInd International Symposium on Groundwater Ecology".

It is hoped that this initial organisation of international personal contacts between groundwater ecologists and the plan to arrange a new meeting in 1978 will further establishment of groundwater ecology in a broad sense. The "Ist International Symposium on Groundwater Ecology" at Schlitz provided the encouragement that such meetings will in the near future lead to the formation of an international association of groundwater ecologists. 


\section{List of papers about subterranean amphipods \\ (printed in a Supplement of Crustaceana)}

Bousfield, E. L.: A new look at the systematics of Gammaroidean Amphipods of the world.

Gibert, J.: Recherches sur la pigmentation de Niphargus virei Chevreux 1896 (Crustacé Amphipode hypogé).

Ginet, R.: Amphipodes troglobies d'Espagne.

Gledhill, T.: Numerical fluctuations of four species of subterranean Amphipods during a five year period.

(the following species are mentioned: Crangonyx subterraneus Bate, Niphargus kochianus kochianus Bate, Niphargus fontanus Bate, Niphargus aquilex Schiödte).

Graf, F.: Evolution du stockage de calcium et des cellules à urates chez Niphargus schellenbergi Karaman.

Holsinger, J. R.: A review of the systematics of the holarctic Amphipod family Crangonyctidae.

Karaman, G. S.: Contribution to the Knowledge of the Amphipoda 78. Niphargus elegans Garbini 1894 (Gammaridae) in Italy.

Mathieu, J.: Variations de la masse de Niphargus rhenorhodanensis Schellenberg 1931 en fonction de l'origine des animaux et de la durée de leur élevage.

Reygrobellet, J. L.: Spermatogenèse et rythmes troglobies chez Niphargus virei Chevreux 1896 (Amphipode, Gammaridè).

Sket, B.: Niphargus (Amphipoda, Gammaridae) im Brackwasser.

(the following species are mentioned: Niphargus caspius Derẑavin, Niphargus hvarensis S. Karaman, Niphargus heberi Schellenberg).

Stock, J. \& Gledhill, T.: The Niphargus kochianus - Group in North-Westhern Europe. 